\title{
ALIEN HERBACEOUS PLANT SPECIES NEW TO LITHUANIA
}

\section{Zigmantas GUDŽINSKAS}

Nature Research Centre, Institute of Botany, Žaliujų Ežerų Str. 49, Vilnius LT-08406, Lithuania

E-mail: zigmantas.gudzinskas@botanika.lt

\begin{abstract}
Gudžinskas Z., 2017: Alien herbaceous plant species new to Lithuania [Naujos Lietuvoje svetimžemės žolinių augalų rūšys]. - Bot. Lith., 23(1): 33-42.

This paper presents information about ten new alien plant species recorded in Lithuania in the period from 1995 to 2014. These species belong to eight families: Cucurbitaceae (Lagenaria siceraria), Juncaceae (Luzula sylvestris), Lamiaceae (Physostegia virginiana, Sideritis montana), Poaceae (Melica altissima, Miscanthus sacchariflorus), Portulacaceae (Claytonia perfoliata), Scrophulariaceae (Digitalis purpurea), Solanaceae (Datura inoxia) and Zygophyllaceae (Tribulus terestris). Three species (Claytonia perfoliata, Sideritis montana and Tribulus terestris) were introduced accidentally, whereas other seven species were introduced deliberately and later escaped from cultivation. One species, Luzula sylvatica, is ascribed to the group of established aliens, whereas other recorded species are treated as casual. Local establishment of Claytonia perfoliata, Digitalis purpurea and Melica altissima is expected, whereas Miscanthus sacchariflorus can become established and even invasive in the future.
\end{abstract}

Keywords: casual species, early detection, established species, introduction pathways.

\section{INTRODUCTION}

Early detection of alien plant as well as other organism species should be based on regular surveys. It has been known that only a small portion of newly arrived alien species become established and even smaller fraction of them become invasive (WITTENBERG \& COCK, 2001). Nevertheless, potential threat to the environment and economy of any alien species can be estimated taking into account precise identification, known or presumed pathways of introduction, means of reproduction, occupied habitats in the native range and in a new area.

Accurate analysis of present distributions and effective modelling of future distributions of alien species are both highly dependent on the availability and accessibility of occurrence data (SIMPSON et al., 2009). Information about new records of alien species in new areas is important, because it enables us to predict occurrence of species in the neighbouring areas, which are affected by the same pathways of introduction. If a species is invasive in other neighbouring regions or in regions with similar climates, such information is vital for rapid response and effective prevention of predicted invasion in a new area.

In recent years, several new naturalized and potentially invasive alien species have been recorded in Lithuania and information about their occurrence has been published (GUDŽINSKAS et al., 2014; GUDŽINSKAS \& Petrulaitis, 2014; GudŽInSKas \& ŽAlnERAVIČIUS, 2015), however, several earlier found species have not been reported and still have not been included into the list of alien plant species of the country. The aim of this publication is to present information about 10 new alien herbaceous plant species, which have been recorded in Lithuania during two last decades.

\section{MATERIALS AND METHODS}

Alien plant species reported in this paper were collected in various regions of Lithuania in the period from 1995 to 2014. Localities of several alien species 
(Claytonia perfoliata, Luzula sylvatica, Miscanthus sacchariflorus and Physostegia virginiana) had been surveyed for several years aiming to reveal dynamics of their populations and to evaluate generative and vegetative reproduction.

Herbarium specimens of the reported plant species were deposited at the Herbarium of the Institute of Botany of the Nature Research Centre (BILAS) in Vilnius. Alien plant species in the text were arranged in alphabetical order. Plant families were provided in accordance with an updated Angiosperm Phylogeny Group classification for the orders and families of flowering plants (APG, 2016). List of examined herbarium specimens is provided in Appendix I. Geographical co-ordinates were indicated according to WGS 1984 standard.

\section{RESULTS}

Claytonia perfoliata Donn ex Willd. (Portulacaceae). Annual, 5-30 cm tall plant. Basal leaves in rosettes, petiolate, with broadly rhombic to deltate blade and obtuse apex. Cauline leaves sessile, blade perfoliate. Inflorescence with one bract-like leaf. Flowers 3-8 $\mathrm{mm}$ in diameter. Petals $2-5 \mathrm{~mm}$ long, white or pinkish. In the native range, $C$. perfoliata grows in areas with disturbed soil cover (MATTHEWs, 2003).

This species is native to the western part of North America (Matтhews, 2003) and is widely naturalized alien in Europe, Australia and New Zealand (RANDALl \& Kessal, 2004). C. perfoliata has been recorded in Germany, Denmark, Poland, Sweden, Norway, Estonia and Finland. In the Netherlands, Denmark, Norway and Sweden it is considered as established non-invasive alien species, whereas in Austria, Estonia, Germany and Poland it is treated as a rare casual species (Rostański \& Sowa, 1987; KuKK, 1999; Nilsson, 2001; EssL \& RabitsCh, 2002; GederaAs et al., 2012; ToKARSKA-GuZIK et al., 2012).

In Lithuania, $C$. perfoliata was first recorded in 2012. Four individuals were found in Vilnius, at Gediminas Av., in a flower-bed among shrubs of $J u$ niperus. The plants flowered at the end of April. In 2013, at the beginning of May, more than 10 individuals were recorded in the same locality, however, next year shrubs densely covered entire surface of the flower-bed and no individuals of $C$. perfoliata were found. This species probably was introduced accidentally with imported ornamental plants from other countries or from nurseries in Lithuania. Currently this species is considered as casual alien; however, its establishment is possible.

Datura inoxia Mill. (Solanaceae). Annual, much branched, $50-150 \mathrm{~cm}$ tall plant. Stem and leaves covered with dense simple hairs and admixture of glandular hairs. Leaves ovate, up to $16 \mathrm{~cm}$ long and $12 \mathrm{~cm}$ wide, with entire or wavy margin. Calyx 5-10 cm long, with 5 or 6 veins and unequal triangular teeth. Corolla with 5 lobes, white, 11-19 cm long. Capsule deflexed, ovoid, with mainly slender, sharp, up to $1 \mathrm{~cm}$ long spines. Seeds brown. In the native range this species grows in areas with disturbed soil cover (ZHANG, 1994; SHOw, 2000).

This species is native to Mexico and South America (SHOw, 2000). It has been recorded in most countries of South and Central Europe as well as in some countries of North Europe (KARLSSON, 1998; EsSL \& Rabitsch, 2002; Verloove, 2006; GederaAs et al., 2012; MedveckÁ et al., 2012). In the Mediterranean region, $D$. inoxia has established, whereas in other regions it is ascribed to the group of casual species (DAISIE, 2009).

In Lithuania, this species was first recorded on the territory of municipal dump Alytus district in 2000. More than 20 well-developed and abundantly flowering individuals were found on slopes of waste and soil piles. In 2002, two individuals of D. inoxia were found in Gegužinè village, Kaišiadorys district, on the edge of forest near cemetery. Large, well-developed individuals with ripening fruits were recorded in the environs of Kiškenai village, Klaipeda district, on the territory of municipal dump in 2003. Individuals of $D$. inoxia probably grew from seeds, which got to dumps and disturbed areas with garden wastes. In Lithuania, this species currently is casual and its establishment is hardly possible.

Datura inoxia is increasingly popular ornamental plant, though in gardening it is often confused with D. metel L. These species can be distinguished by the character of capsules and hairiness. Capsules of D. metel are covered with numerous conical tubercules, whereas these of $D$. inoxia are covered with dense, up to $1 \mathrm{~cm}$ long, sharp spines. Leaves and stem of $D$. metel are covered with sparse simple hairs 
(only young leaves are densely hairy), whereas D. inoxia is covered with dense simple hairs with admixture of glandular hairs.

Digitalis purpurea L. (Scrophulariaceae). Perennial, occasionally annual or biennial, $60-150 \mathrm{~cm}$ tall plant. Leaves and stem usually grey pubescent and with glandular hairs. Basal leaves up to $15 \mathrm{~cm}$ long and $5-10 \mathrm{~cm}$ wide, with narrowly winged petiole. Stem leaves sessile or short petiolate, usually acuminate. Corolla purple, occasionally white, $3-4.5 \mathrm{~cm}$ long, spotted inside. Capsule $1.5 \mathrm{~cm}$ long. In the native range this species usually grows on forest edges, in forest glades and on slopes (HEYwood, 1972b).

This species is native to West Europe, the southwestern part of Central Europe and North Africa (HeYwood, 1972b; Marhold, 2011). In many European countries, it is cultivated and occurs as established or casual alien (MARHOLD, 2011; TOKARSKA-GuzIK et al., 2012). In the Czech Republic and Finland, it is considered as locally invasive species (PYšEK et al., 2002; НäMET-Ahtı, 2005). D. purpurea has also naturalized in Australia and New Zealand as well as in some regions of Asia and North America (Randall \& Kessal, 2004; Howell, 2008; Cullina et al., 2011).

In Lithuania, this species as escaped from cultivation was first registered in 1995. It was found in Plunge district, Žemaitija National Park, on the edge of forest, under power transmission line. The group consisted of more than 20 individuals. Most of individuals were in a rosette stage and five generative individuals were at the end of flowering. Another record of $D$. purpurea was made in a forest on a slope close to the cemetery of Jeruzale (Vilnius) in 2004. Three individuals were recorded and two of these were at the beginning of flowering. In 2014, D. purpurea was also recorded on an open slope in the environs of Kurtuvenai cemetery, Šiauliai district. One individual was at the beginning of flowering, whereas another was in rosette stage. Currently, D. purpurea is casual alien, however, this increasingly popular ornamental plant can become more frequent escaped and its local establishment is possible.

Lagenaria siceraria (Molina) Standley (Cucurbitaceae). Annual plant with up to $5 \mathrm{~m}$ long, branched, sulcate-angular stem. Leaves large, up to $35 \mathrm{~cm}$ in di- ameter, ovate-cordate or reniform-ovate, undivided or with 3 to 5 lobes and irregularly dentate margin, on both surfaces puberulent. Plants monoecious. Male and female flowers funnelform, about $2 \mathrm{~cm}$ in diameter, with white or yellowish white corolla. Fruit various in size and shape. In the native range this species usually grows in areas with disturbed soil cover (NEE, 1990; Lu \& JEFFREy, 2011).

This species is probably native to tropical Africa (KARLSSON, 2010) and is widely cultivated in tropical, subtropical, and occasionally in temperate regions of the world (NEE, 1990; Howell, 2008; Karlsson, 2010; Lu \& Jefrrey, 2011). In Northern and Eastern Europe, L. siceraria has been cultivated since the late 20th century; therefore, only recently it has been reported occurring as escaped species. This species has been recorded on rubbish heaps in Denmark and Sweden (KARLSSON, 2010).

In Lithuania, L. siceraria was first recorded in Ignalina district, in the environs of Kazitiškis, on the territory of closed municipal dump, on piles of ground and waste mixture in 2003. Well-developed and intensively flowering individuals occupied significant area of the piles and covered about $30 \%$ of the surface. Fruits at the time of investigation were in early stage of development and up to $15 \mathrm{~cm}$ long. Seeds of $L$. siceraria have probably been brought into this locality with garden or kitchen refuse. In Lithuania, this species is casual alien and its establishment in the country as well as in the whole Baltic region is hardly possible. Nevertheless, with the increase of frequency of its cultivation, $L$. siceraria can be occasionally found in wastelands, on rubbish or compost heaps.

Luzula sylvatica (Huds.) Gaudin (Juncaceae). Perennial, $60-80 \mathrm{~cm}$, sometimes up to $100 \mathrm{~cm}$ tall, loosely caespitose plant with horizontal branched rhizomes. Basal leaves 4-12 mm wide and up to $40 \mathrm{~cm}$ long. Inflorescence usually lax, up to $20 \mathrm{~cm}$ long. Bracteoles membranous, ovate, up to $2 \mathrm{~mm}$ long, sparsely ciliate. Capsule dark brown, oblong or ovoid, usually $2.0-4.0 \mathrm{~mm}$ long. Seeds brown, $1.2-1.9 \mathrm{~mm}$ long. In the native range, L. sylvatica occurs in damp, acidic, usually shaded habitats mainly in forests and along mountain streams (CHRTEK \& KŘIISA, 1980).

This species is native to West, Central and South Europe, the Caucasus and West Turkey. Though in 
Norway L. sylvatica is native, in Sweden it occurs as alien species (LJUNGSTRAND, 2001). As alien species, L. sylvatica has also been reported in New Zealand (BuCKLeY, 1992).

In Lithuania, L. sylvatica was first recorded in Trakai district, in forest, which is unmanaged part of former Užutrakis Manor Park in 2005. Three patches of this species were recorded within a distance of $1 \mathrm{~m}$ to $1.5 \mathrm{~m}$ among them. The largest patch occupied $2 \mathrm{~m}^{2}$, whereas two other patches were much smaller, $0.3 \mathrm{~m}^{2}$ and $0.2 \mathrm{~m}^{2}$. Coverage of the tree layer in the habitat was about $60 \%$, whereas shrub layer was very sparse and its coverage was less than 10\%. In May of 2005 , L. sylvatica was with numerous inflorescences. In 2016, the second group of plants was recorded about $150 \mathrm{~m}$ north-east of the previous stand, on the edge of very dense mixed forest. Coverage of both the tree and shrub layers in this habitat was almost the same, i.e. $70 \%$ and $60 \%$, respectively. In very shaded habitat, L. sylvatica flowered poorly, only six inflorescences were recorded. This species has probably been introduced during the establishment of Užutrakis Manor Park. This park was designed by the famous French landscape architect Édouard François André at the turn of the 19th and 20th centuries (JANUŠKEVIČIUS, 2004). In Lithuania, in all parks created by this architect, several common species of Central European origin have been sown and some of these, e.g. Luzula luzuloides and Poa chaixii, have become naturalized (GUDžINSKAS, 1997). Luzula sylvatica might have been introduced intentionally or accidentally with seeds of other plants intended for park lawns. Currently, L. sylvatica should be treated as established species, though its further spread is hardly possible. In new localities, it can appear only because of fresh introductions and later escape.

Melica altissima L. (Poaceae). Perennial, 60 $150 \mathrm{~cm}$ tall rhizomatous plant. Leaves $5-15 \mathrm{~mm}$ wide. Flowers arranged in a dense, narrowly cylindrical, 10-20 cm long, usually one-sided, in lower part interrupted spike. Spikelets numerous, 7-12 mm long, with one to two fertile florets. Glumes $7.0-10.5 \mathrm{~mm}$, sub-acute to obtuse, with broad hyaline margins. Lemmas equalling the glumes, hairless, but minutely rough. In the native range this species grows in light forest and scrub habitats, in meadows and on slopes (Tutin, 1980; Green, 2009).
This species is native to the south-eastern Europe, the southern part of Central Europe and western Asia (Tutin, 1980; Zhenlan \& Phillips, 2006). It is widely cultivated in gardens as ornamental grass (SHANKLIN \& LeSLIE, 2009). At the beginning of the 20th century, M. altissima as alien species was recorded in Poland (Rostański \& Sowa, 1987; GŁazek, 1997; ToKARSKA-GuzIK et al., 2012). In the first half of the 20th century, it was found in Sweden and Norway (GederaAs et al., 2012). Quite recent records of this escaped ornamental plant have been made in the British Isles (Shanklin \& Leslie, 2009; Green, 2009). In Norway, M. altissima is considered as established (GEDERAAs et al., 2012), whereas in other countries it is ascribed to the group of casual aliens.

In Lithuania, M. altissima was first recorded on a wasteland at the cemetery of Traupis village, Anykščiai district in 2007. Two dense patches of this species occupied $1.5 \mathrm{~m}^{2}$ and $2 \mathrm{~m}^{2}$, respectively. Plants observed in the second half of June were well developed and at the end of flowering. Reproduction by seeds was not confirmed, however, it is evident that this plant easily reproduces by rhizomes. Currently, $M$. altissima occurs as a casual alien in Lithuania, however, its establishment and spread in the future is probable and its occurrence can increase with the increase of the frequency of its cultivation in gardens.

VILKONIS (2008) has reported about the record of M. transsilvanica Schur. and indicated that this alien species occurs in waste places in Lithuania, though he has not provided any exact localities and no herbarium specimens have been recorded in institutional herbaria. The analysis of published photograph of the plant, which was identified as $M$. transsilvanica (VILKONIS, 2008: 373, Fig. 2), revealed that it has evidently glabrous lemmas and one-sided spike. These features are characteristic of $M$. altissima, whereas $M$. transsilvanica is characterized by densely hairy lemmas and cylindrical spike. Therefore, plants reported by VILKONIS (2008) probably belong to $M$. altissima and indication of escaped $M$. transsylvanica in Lithuania should be treated as erroneous.

Miscanthus sacchariflorus (Maxim.) Hack. (Poaceae). Perennial, 60-160 $\mathrm{cm}$ tall plant with long slender rhizomes. Leaves $20-50 \mathrm{~cm}$ long and $0.5-1.5 \mathrm{~cm}$ wide, glabrous, with prominent midrib. 
Panicle 7-30 cm long, axis 5-15 cm long, with 4-24 racemes. Spikelets 4-6 mm long, pilose, awnless. Callus hairs 8-12 $\mathrm{mm}$ long, exceeding the spikelet. Glumes subequal, membranous, 4-6 mm long. Lower glume densely pilose with long hairs on margins. Caryopsis oblong. Reproduces vegetatively by rhizomes forming quite dense stands. In the native range this species grows on mountain slopes and on river banks (Chen \& Renvoize, 2006).

This species is native to East Asia (East Russia, China, Korean peninsula and Japan) and widely cultivated as an ornamental plant and for biofuel (CHEN \& Renvoize, 2006; Clifton-Brown et al., 2008). In 1980, this species was registered in Austria (EssL \& RABITSCH, 2002), whereas in 1999, it was recorded in Belgium (Verloove, 2006). Recently, this species has been found in Poland (ToKARSKA-GuzIK et al., 2012; Pliszko, 2016a). M. sacchariflorus is ascribed to the group of casual alien species in all three countries. In the north-eastern regions of the United States of America, this species is invasive (BonIN et al., 2014).

In Lithuania, quite large stand of $M$. sacchariflorus was first found in 1999. It was recorded in Vilnius, on a wet shore of small lake, on the edge of shrub stand. At the end of September, most of shoots were in vegetative condition and only about $3 \%$ of these were with well-developed inflorescences. At the beginning of September 2014, the same locality was re-visited; however, no individuals of this species were recorded. The colony has become extinct, because the whole area formerly occupied by $M$. sacchariflorus was covered by a dense stand of shrubs and young trees. Another locality of this species was revealed in about $0.7 \mathrm{~km}$ south-east of the first locality, in a wasteland at Krokuva street. The stand of this species occupied about $120 \mathrm{~m}^{2}$. Only several shoots were with inflorescences, whereas most of these were in vegetative stage. Currently, M. sacchariflorus is a casual alien; however, this perennial rhizomatous plant can persist for a long time and spread by rhizomes. Therefore, establishment and further spread of this species in Lithuania is possible.

Another species of this genus, $M$. sinensis Andersson, is increasingly cultivated in gardens. Though this species has not been recorded outside the areas of cultivation in Lithuania, its escape is highly probable in the future. M. sacchariflorus and M. sinen- sis can be easily distinguished in generative stage. Spikelets of $M$. sacchariflorus are awnless, whereas those of $M$. sinensis are awned.

Physostegia virginiana (L.) Benth. (Lamiaceae). Perennial, rhizomatous, $40-120 \mathrm{~cm}$ tall plant. Leaves 4-12 cm long and 1-3 cm wide, lanceolate, coarse toothed. Inflorescence a solitary 5-20 cm long spike or panicle with numerous flowers and 5-20 mm long bracts. Calyx 5-20 mm long, narrowly campanulate, with glandular hairs. Corolla $20-30 \mathrm{~mm}$ long, pink or purplish, sometimes white. Nutlets triangular (Gleason \& Cronquist, 1991; Whiteley, 2000). In the native range, $P$. virginiana grows in moist to mesic prairies, along woodland borders, in moist meadows along rivers (GLEASON \& CRONQUIST, 1991; MoHLENBrock, 2002).

This species is native to the eastern Canada, eastern and central United States of America and northeastern Mexico (CANTINo, 1982). Although P. virginiana is a frequently cultivated ornamental plant in Europe, escaped from cultivation it has rarely been recorded. This species has been reported escaped in Austria (Essl \& Rabitsch, 2002), France, Germany, Hungary, Italy, Poland and Slovakia (DAISIE, 2009; Medvecká et al., 2012; Pliszko, 2016a).

In Lithuania, $P$. virginiana was first recorded in 1999. Tree groups of plants occurred along the edge of wet shrub grove close to a small lake. At the end of September, the plants were still with flowers on the top of inflorescence, though at the base of the inflorescence, the nutlets were already ripened. In September of 2014, in the same locality, no individuals of this species were recorded, because entire habitat was covered by dense shrubs. Currently, $P$. virginiana is a casual species; however, in the future its establishment is probable.

Sideritis montana L. (Lamiaceae). Annual, 10$40 \mathrm{~cm}$ tall, with erect stem. Stem and leaves covered with spreading long hairs and frequently with sessile oil globules. Leaves oblong or elliptic, usually crenulate, shortly petiolate or sessile. Inflorescence often extending almost the whole length of stem. Verticillasters in axils of leaves. Calyx about $8 \mathrm{~mm}$ long, green, with equal teeth, terminating in about $2 \mathrm{~mm}$ long mucro. Corolla shorter than calyx, 6-7 mm long, yellow turning brownish black at the end of 
anthesis. Nutlets pale brown, with fine reticulations (Heywood, 1972a). All specimens of S. montana collected in Lithuania belong to the type subspecies (S. montana subsp. montana).

Sideritis montana is native to the Mediterranean region, south-western and Central Asia (HEYwood, 1972a). As casual alien species, it has been recorded in the Czech Republic, Germany, Poland, Norway, Sweden, Latvia and Estonia (Rostański \& Sowa, 1987; Karlsson, 1998; Jehlík \& Dostálek, 2008; ToKarska-GuZiK et al., 2012; Priedītis, 2014).

In Lithuania, $S$. montana was first recorded in Kedainiai, in the territory of grain mill yard in 1999. Two flowering individuals were recorded on the railway. In 2000, this species was found in two localities in Alytus. One locality was also in a grain mill yard, another locality was revealed on a railway leading to the grain mill. In all localities, the plants recorded in August were with opened flowers on the apex of the inflorescence, whereas at the bottom of inflorescence almost ripe fruits were found. This species was probably introduced with grain imported from South European countries. Though $S$. montana can produce seeds, currently, it is a rare casual alien and its naturalization in the nearest future is hardly possible.

Tribulus terrestris L. (Zygophyllaceae). Annual, procumbent, 5-30 $\mathrm{cm}$ tall, usually pubescent plant with simple or much branched stem. Leaves opposite, paripinnate, with 5-8 pairs of pinnae. Flowers 4-5 $\mathrm{mm}$ in diameter, with yellow petals. Fruit of five stellately arranged hard, rugose carpels with two or more stout spines. In the native range, it grows in dry open habitats, often as a weed (TuTIN, 1968).

This species is native to the Mediterranean region, South Europe and West Asia and is widely spread as alien or invasive species in the temperate regions of the world with dry climates (TuTIN, 1968; HanF, 1983). In 1866, T. terrestris was recorded in Poland (Aвromeit et al., 1898; RostańsKi \& Sowa, 1987; ToKARSKA-GuzIK et al., 2012) and until present it is a rare casual alien. This species as casual alien has also been registered in Norway (GEDERAAS et al., 2012).

In Lithuania, this species was first recorded in Kedainiai, on a railway in grain mill yard in 1999. Four flowering individuals were found. At the beginning of August, all individuals were at the first half of flowering, and only few unripe fruits were observed. This species has been introduced with imported grain, though in some European countries it has been introduced with wool (Verloove, 2006). Currently, T. terrestris is a casual alien and its establishment in the future is hardly probable.

Alien plant species reported in this paper belong to eight families: Cucurbitaceae (Lagenaria siceraria), Juncaceae (Luzula sylvestris), Lamiaceae (Physostegia virginiana, Sideritis montana), Poaceae (Melica altissima, Miscanthus sacchariflorus), Portulacaceae (Claytonia perfoliata), Scrophulariaceae (Digitalis purpurea), Solanaceae (Datura inoxia) and Zygophyllaceae (Tribulus terestris). Representatives of one family (Zygophyllaceae) and six genera (Claytonia, Lagenaria, Miscanthus, Physostegia, Sideritis and Tribulus) have not been recorded in Lithuania before.

\section{DISCUSSION}

Analysis of the introduction pathways revealed that two species (Sideritis montana and Tribulus terestris) have most probably been introduced accidentally with imported grain. These species are common weeds of various crops in the regions with warm and dry climates (Hanf, 1983; JeHLík \& DostáleK, 2008; RANDALL, 2012) and in Lithuania they have been recorded in grain mill yards or on railways close to grain mills. Import of grain was an important pathway of alien species introduction to Lithuania in the second half of the 20th century (GUDŽINSKAS, 1994; VAINORIENÉ \& GUDŽINSKAS, 2009); however, the importance of this vector during the last two decades has decreased, because the import of grain to Lithuania has declined significantly (KRIŠČIUKAITIENĖ et al., 2010). Claytonia perfoliata has also been introduced accidentally, probably with ornamental shrubs from nursery. Seven other species reported in this paper, have been introduced in Lithuania deliberately as ornamental plants and later escaped from cultivation. Increase of the number of escaped species, formerly being only in cultivation, is a characteristic feature of contemporary alien flora formation in many European countries (Pergl et al., 2016; Pliszko, 2016b, etc.).

Misccanthus sacchariflorus has currently been treated as casual species, however, in the future it, together with other cultivated species of this genus, 
can start spreading, become established or even invasive. Therefore, species of this genus should be constantly surveyed and measures of population control taken, if necessary. Local establishment of Digitalis purpurea and Melica altissima is also expected, however, their invasion in the nearest future is unlikely. Establishment of Claytonia perfoliata is also possible in the future, especially if cases of new introductions increase in the future. Luzula sylvatica has been ascribed to the group of established species, but its spread to new territories is not expected.

Any accidentally or deliberately introduced and escaped alien plant species should not be ignored (Rob, 1973; Rotherham, 2001; Simpson et al., 2009). Regular surveillance of areas and habitats with high probability of occurrence of new alien plant species as well as detection, identification and evaluation of potential spread of alien species are very important tasks aiming to take rapid response and prevent future invasions. Though many of newly detected species usually occur in heavily disturbed habitats, some of these settle in semi-natural or natural habitats, especially in the areas adjacent to settlements, industrial and agricultural areas, roads and bodies of water.

\section{REFERENCES}

Abromeit J., Jentzsch A., Vogel G., 1898: Flora von Ost- und Westpreussen, 1. - Berlin.

APG, 2016: An update of the Angiosperm Phylogeny Group classification for the orders and families of flowering plants. APG IV. - Botanical Journal of the Linnaean Society, 181: 1-20.

Bonin C.L., Heaton E.A., Barb J., 2014: Miscanthus sacchariflorus - biofuel parent or new weed? GCB Bioenergy, 6: 629-636.

BuCKLEY G.P., 1992: Ecology and Management of Coppice Woodlands. - London.

CAntino P.D., 1982: A monograph of the genus Physostegia (Labiatae). - Contributions from the Gray Herbarium of Harvard University, 211: 1-105.

Chen S., Renvoize S.A., 2006: Miscanthus Andersson. - In: Zhengyi W., Raven P.H., Deyuan H. (eds), Flora of China. Poaceae, 22: 581-583. Beijing-St. Louis.

ChrteK J., KŘISA B., 1980: Luzula DC. - In: Tutin T.G., Heywood V.H., Burges N.A., Moore D.M., Valentine D.H., Walters S.M., Webb D.A. (eds),
Flora Europaea, 5: 111-116. - Cambridge.

Clifton-Brown J., Chiang Y.-C., Hodkinson T.R., 2008: Miscanthus: genetic resources and breeding potential to enhance bioenergy production. In: VERMERRIS W. (ed.), Genetic Improvement of Bioenergy Crops: 295-308. - Gainesville.

Cullina M.D., Connolly B., Sorrie B., Somers P., 2011: The vascular plants of Massachusetts: A county checklist, first revision. - Westborough.

DAISIE, 2009: Handbook of Alien Species in Europe. - Berlin.

Essl F., RABITSCH W., 2002: Neobiota in Österreich. - Wien.

Gederaas L., Moen T.L., SkJelseth S., Larsen L.-K. (eds), 2012: Alien species in Norway with the Norwegian Black List 2012. - Trondheim.

GŁazek T., 1997: Nowe dla Polski stanowiska Melica altissima (Poaceae). - Fragmenta Floristica et Geobotanica. Series Polonica, 4: 374-377.

Gleason H.A., Cronquist A., 1991: Manual of Vascular Plants of Northeastern United States and Adjacent Canada. - New York.

Green P.R., 2009: First British record for self-sown Melica altissima? - Botanical Society of the British Isles News, 112: 34.

GuDŽINSKAs Z., 1994: Alien species of Lithuania. Vilnius.

Gudžinskas Z., 1997: Conspectus of alien plant species of Lithuania. 2. Poaceae. - Botanica Lithuanica, 3(2): 107-134.

Gudžinskas Z., Petrulaitis L., 2014: Helianthus grosseserratus, a new alien plant species in Lithuania. - Botanica Lithuanica, 20(2): 173-176.

Gudžinskas Z., Petrulaitis L., Arlikevičiūtė L., 2014: Vaccinium macrocarpon - a new alien plant species in Lithuania. - Botanica Lithuanica, 20(1): 41-45.

GUDŽINSKAS Z., ŽALNERAVIČIUS E., 2015: Notes on alien plant species Amorpha fruticosa new to Lithuania. - Botanica Lithuanica, 20(2): 173-176.

Hämet-Ahti L., Kurtto A., Lampinen R., Pitrainen M., Suominen J., Ulvinen T., Uotila P., VÄre H., 2005: Lisäyksiä ja korjauksia retkeilykasvion neljänteen painokseen. - Lutukka, 21(2): 41-85.

HanF M., 1983: The Arable Weeds of Europe: With their Seedlings and Seeds. - Oxford.

Heywood V.H., 1972a: Sideritis L. - In: Tutin T.G., Heywood V.H., Burges N.A., Moore D.M., Val- 
entine D.H., Walters S.M., Webb D.A. (eds), Flora Europaea, 3: 139-143. - Cambridge.

HeYwood V.H., 1972b: Digitalis L. - In: Tutin T.G., Heywood V.H., Burges N.A., Moore D.M., VaLentine D.H., Walters S.M., Webb D.A. (eds), Flora Europaea, 3: 239-241. - Cambridge.

Howell C., 2008: Consolidated list of environmental weeds in New Zealand. - DOC Research \& Development Series, 292: 1-42.

JANUŠKEVIČIUS L., 2004: Lietuvos parkai. - Kaunas.

Jehlík V., Dostálek J., 2008: Influence of railway transport in the South-East of Slovakia on formation of adventive flora in Central Europe. Biodiversity Research and Conservation, 11-12: 27-32.

KARLSSON T., 1998: Förteckning över svenska kärlväxter. - Svensk Botanisk Tidskrift, 91: 241-560.

Karlsson T., 2010: Cucurbitaceae. - In: Jonsell B. (ed.), Flora Nordica. Thymelaeaceae to Apiaceae, 6: 70-78. - Stockholm.

Kriščiukaitienè I., Andrikienè S., Galnaitytė A., JEDIK A., 2010: Grūdų rinkos prognozès iki 2020 metų. - Management Theory and Studies for Rural Business and Infrastructure Development, 23(4): 1-13.

KUKK T., 1999: Eesti taimestik. - Tartu-Tallinn.

LuUNGSTRAND E., 2001. Luzula sylvatica found on mount Kullaberg in Skane, Sweden. - Botaniska Notiser, 134(1): 6-14.

Lu A., Jefrerey C., 2011: Lagenaria - In: Wu Z.Y., Raven P.H., Hong D.Y. (eds), Flora of China. Cucurbitaceae through Valerianaceae, with Annonaceae and Berberidaceae, 19: 53. - BeijingSt. Louis.

MARHOLD K., 2011: Scrophulariaceae.-In: Euro+Med Plantbase - the information resource for EuroMediterranean plant diversity. http://ww2.bgbm. org/EuroPlusMed.

Matthews J.F., 2003: Portulaca Linnaeus. - In: Flora of North America north of Mexico, 4: 496-501.New York-Oxford.

Medvecká J., Kliment J., Májeková J., Halada L., Zaliberová M., Gojdičová E., Feráková V., JAROLÍMEK I., 2012: Inventory of the alien flora of Slovakia. - Preslia, 84: 257-309.

MohlenBrock R.H., 2002: Vascular Flora of Illinois. - Carbondale.

NeE M., 1990: The Domestication of Cucurbita (Cu- curbitaceae). - Economic Botany, 44(3 supplement): 56-68.

Nilsson Ö., 2001: Portulacaceae. - In: Jonsell B. (ed.), Flora Nordica. Chenopodiaceae to Fumariaceae, 2: 76-83. - Stockholm.

Pergl J., Sádlo J., Petřík P., Danihelka J., Chrtek J. Jr., Hejda M., Moravcová L., Perglová I., Štajerová K., Pyšek P., 2016: Dark side of the fence: ornamental plants as a source for spontaneous flora of the Czech Republic. - Preslia, 88: 163-184.

PliszKo A., 2016a: A casual occurrence of Physostegia virginiana (Lamiaceae) in Poland. - Acta Musei Silesiae. Scientiae Naturales, 65: 47-50.

Pliszko A., 2016b: Additions to vascular plant flora of the Western Suwałki Lakeland, north-eastern Poland. - Bot. Lith., 22(2): 178-181.

Priedītis N., 2014: Latvijas augi. - Rīga.

Pyšek P., SÁdlo J., Mandák B., 2002. Catalogue of alien plants of the Czech Republic. - Preslia, 74: 97-186.

Randall R., Kessal O., 2004: National List of Naturalised Invasive and Potentially Invasive Garden Plants. - Sydney.

Randall R.P., 2012: A Global Compendium of Weeds (Second Edition). - Western Australia.

Rов C.M., 1973: Garden escapes and naturalized plants. - In: GreEN P.S. (ed.), Plants wild and cultivated: 146-151. - London.

Rostański K., Sowa R., 1987: Alfabetyczny wykaz efemerofitów Polski. - Fragmenta Floristica et Geobotanica, 31-32: 151-205.

Rotherham I.D., 2001: Himalayan balsam - the human touch. - In: BradLEY P. (ed.), Exotic Invasive Species - Should we be Concerned?: 41-50. Birmingham.

Shanklin I., Leslie A., 2009: Melica altissima found in Cambridge. - Botanical Society of the British Isles News, 111: 38.

SHow J.M.H., 2000: Datura Linnaeus. - In: Cullen J., Knees S.G., Cubey H.S. (eds), The European Garden Flora, 6: 247-248. - Cambridge.

Simpson A., Jarnevich C., Madden J., Westbrooks R., Fournier C., Mehrhoff L., Browne M., Graham J., SELLERS E., 2009: Invasive species information networks: collaboration at multiple scales for prevention, early detection, and rapid response to invasive alien species. - Biodiversity, 10(2-3): 5-13. 
Tokarska-Guzik B., Dajdok Z., Zając M., Zając M., Urbisz A., Danielewicz W., HoŁdyński C., 2012: Rośliny obcego pochodzenia w Polsce ze szczególnym uwzględnieniem gatunków inwazyjnych. - Warszawa.

Tutin T.G., 1968: Zygophyllaceae. - In: Tutin T.G., Heywood V.H., Burges N.A., Moore D.M., Valentine D.H., Walters S.M., WebB D.A. (eds), Flora Europaea, 2: 204-205. - Cambridge.

Tutin T.G., 1980: Melica L. - In: Tutin T.G., HeYwood V.H., Burges N.A., Moore D.M., Valentine D.H., Walters S.M., WebB D.A. (eds), Flora Europaea, 5: 178-179. - Cambridge.

VAINORIENĖ R., GudžInSKas Z., 2009: Diversity of wild plant seeds brought to Lithuania with imported grain. - Bot. Lith., 15(4): 237-244.
Verloove F., 2006: Catalogue of neophytes in Belgium (1800-2005). - Scripta Botanica Belgica, 39: $1-89$.

VILKONIS K.K., 2008: Lietuvos žaliasis rūbas. - Kaunas.

Whiteley A.C., 2000: Physostegia Bentham. - In: Cullen J., KneEs S.G., Cubey H.S. (eds), The European Garden Flora, 6: 199. - Cambridge.

Wittenberg R., Cock M.J.W., 2001: Invasive Alien Species - a Toolkit of Best Prevention and Management Practices. - Wallingford.

Zhang Z., Lu A., D’Arcy W.G., 1994: Solanaceae In: Wu Z.Y., RAVEN P.H., Hong D.Y. (eds), Flora of China, 17: 300-332. - Beijing-St. Louis.

Zhenlan W., Phillips S.M., 2006: Melica Linnaeus. In: Wu Z.Y., Raven P.H., Hong D.Y. (eds), Flora of China, 22: 216-223. - Beijing-St. Louis.

\section{NAUJOS LIETUVOJE SVETIMŽEMĖS ŽOLINIŲ AUGALŲ RŪŠYS}

\section{Zigmantas GuDžINSKAS}

\section{Santrauka}

Straipsnyje pateikiami duomenys apie dešimt Lietuvoje naujų svetimžemių žolinių augalų rūšių, kurios priklauso aštuonioms šeimoms: Cucurbitaceae (Lagenaria siceraria), Juncaceae (Luzula sylvestris), Lamiaceae (Physostegia virginiana, Sideritis montana), Poaceae (Melica altissima, Miscanthus sacchariflorus), Portulacaceae (Claytonia perfoliata), Scrophulariaceae (Digitalis purpurea), Solanaceae (Datura inoxia) ir Zygophyllaceae (Tribulus terestris). Trijų rūšių augalai (Claytonia perfoliata, Sideritis montana ir Tribulus terestris) i Lietuvą pateko atsitiktinai, o kitų rūšių augalai buvo introdukuoti, auginami ir sulaukèjo. Viena straipsnyje nagrinejjama rūšis (Luzula sylvatica) priskirta prie įsitvirtinusių, o visų kitų rūšių augalai dabar priskiriami prie neisitvirtinusių rūšiu grupès. İvertinus visą informaciją ir apibendrinus stebejimų rezultatus galima teigti, kad Claytonia perfoliata, Digitalis purpurea ir Melica altissima ateityje gali įsitvirtinti ir sudaryti pastovias populiacijas, o Misccanthus sacchariflorus gali ne tik natūralizuotis, bet ir tapti invaziniu augalu. 


\section{APPENDIX 1. THE LIST OF EXAMINED HERBARIUM SPECIMENS}

Claytonia perfoliata Donn ex Willd. - Vilnius, Gediminas Av., in front of the parliament building, in flower-bed among shrubs of Juniperus, 26 April 2012. Leg. et det. Z. Gudžinskas. 54.690377 N, 25.260990 E.

Datura inoxia Mill. - 1. Alytus district, $5 \mathrm{~km}$ north-east of Alytus, environs of Jurkionys village, territory of municipal dump, on slopes of waste and soil piles, quite abundant, 25 August 2000. Leg. et det. Z. Gudžinskas. 54.423638 N, 24.125441 E; 2. Kaišiadorys district, Gegužinè village, vicinity of cemetery, in a wasteland on the edge of forest, two individuals, 29 June 2002. Leg. et det. Z. Gudžinskas. $55.008550 \mathrm{~N}, 24.507423 \mathrm{E}$; 3. Klaipèda district, 1 $\mathrm{km}$ south-east of Kiškenai village, territory of municipal dump, on a slope of waste pile, two individuals with ripening fruits, 4 August 2003. Leg. et det. Z. Gudžinskas. 55.682111 N, 21.301806 E.

Digitalis purpurea L. - 1. Plungè district, Žemaitija National Park, the Plokštinè forest, on the edge of the forest, under power transmission line, 26 July 1995. Leg. et det. Z. Gudžinskas. 56.008558 N, 21.886515 E; 2. Vilnius, Jeruzale, environs of Jeruzale cemetery, on a slope overgrown with deciduous trees, three individuals, 22 July 2004. Leg. et det. Z. Gudžinskas. 54.741133 N, 25.281900 E; 3. Šiauliai district, Kurtuvenai, environs of cemetery, on disturbed slope, two individuals, 30 July 2014. Leg. et det. Z. Gudžinskas. 55.827162 N, 23.042763 E.

Lagenaria siceraria (Molina) Standley - Ignalina district, $1.7 \mathrm{~km}$ south of Kazitiškis, territory of former municipal dump, on heaps of mixture of soil and wastes, quite abundant, 7 August 2003. Leg. et det. Z. Gudžinskas. 55.427782 N, 26.137705 E.

Luzula sylvatica (Huds.) Gaudin - 1. Trakai district, $2.5 \mathrm{~km}$ north of Trakai, Užutrakis, on a slope overgrown with pines and deciduous trees, three patches, 27 May 2005. Leg. et det. Z. Gudžinskas. $54.65900 \mathrm{~N}, 24.949250 \mathrm{E} ; 2$. Trakai district, $2.5 \mathrm{~km}$ north of Trakai, Užutrakis, on the edge of a dense pine and deciduous tree stand, colony occupying $2.5 \mathrm{~m}^{2}, 18$ June 2016. Leg. et det. Z. Gudžinskas. 54.659844 N, 24.947895 E.

Melica altissima L. - Anykščiai district, Traupis, in a wasteland at the cemetery, two patches $\left(1.5 \mathrm{~m}^{2}\right.$ and $\left.2 \mathrm{~m}^{2}\right), 21$ June 2007. Leg. et det. Z. Gudžinskas. $55.514815 \mathrm{~N}, 24.742428 \mathrm{E}$.

Miscanthus sacchariflorus (Maxim.) Hack. - Vilnius, Šnipiškès, between Geležinis Vilkas and Lvovas Str., on the edge of shrub stand on a wet shore of a small lake (about $30 \mathrm{~m}^{2}$ ), 30 September 1999. Leg. et det. Z. Gudžinskas. 54.701846 N, 25.266437 E.

Physostegia virginiana (L.) Benth. - Vilnius, Šnipiškès, on the shore of a small lake near Geležinis Vilkas Str., on the edge of wet shrub grove, three groups of plants, 30 September 1999. Leg. et det. Z. Gudžinskas. 54.701780 N, 25.266934 E.

Sideritis montana L. - 1. Kèdainiai, southwestern edge of the city, on railway in the grain mill yard, two individuals, 9 August 1999. Leg. et det. Z. Gudžinskas. 55.254788 N, 23.993836 E; 2. Alytus, northern industrial part of the city, on railway in the grain mill yard, five individuals, 24 August 2000. Leg. et det. Z. Gudžinskas. 54.429790 N, $24.012866 \mathrm{E} ; 3$. Alytus, northern industrial part of the city, on railway towards the grain mill yard, two individuals, 24 August 2000. Leg. et det. Z. Gudžinskas. $54.427313 \mathrm{~N}, 24.010069 \mathrm{E}$.

Tribulus terrestris L. - Kèdainiai, southwestern edge of the city, on railway in the grain mill yard, four individuals, 9 August 1999. Leg. et det. Z. Gudžinskas. 55.254797 N, 23.993832 E. 